\title{
ASSESSMENT OF THE OPPORTUNITIES FOR DEVELOPMENT OF A FACULTY IN AN ACADEMIC AND SCIENTIFIC UNIT
}

\author{
Magdalena KASPROWICZ ${ }^{*}$, Grażyna OWCZARCZYK-SZPAKOWSKA ${ }^{2}$ \\ ${ }^{1}$ UTP University of Science and Technology in Bydgoszcz; mkasprowicz@utp.edu.pl, \\ ORCID: 0000-0002-7549-6050 \\ ${ }^{2}$ UTP University of Science and Technology in Bydgoszcz, Department of Economics and Business Law; \\ gszpakowska@op.pl, ORCID: 0000-0002-3678-4519 \\ * Correspondence author
}

Purpose: The purpose of the article is to analyze the strengths and weaknesses as well as opportunities and threats of the scientific unit (Faculty) and assess the development possibilities of this unit.

Design/methodology/approach: The main research problem undertaken concerns the analysis of the Faculty's Development Strategy based on the main source document which is the Faculty's Development Strategy for 2012-2020. Based on a specific research problem, the following hypotheses were formulated: effective management of the Faculty's operation influences the achievement of the set goal of the Faculty's development, efficient monitoring of the Department's strategy allows the organization to operate effectively, a properly prepared strategy should be based on the correct recognition of the potential of the organization and the environment.

Findings: The analysis of strengths, weaknesses, opportunities and threats has allowed us to verify hypotheses and identify problems that the Unit may face in the future.

Research limitations/implications: Based on the analysis of the Faculty's interior and surroundings, it should be stated that the Faculty's Development Strategy should be evaluated in the near future. A strategy monitoring system should also be developed taking into account the results obtained.

Practical implications: The recommendation is to develop a staff development strategy, which may contribute to accelerating the independence of the Faculty and, consequently, to obtain doctoral rights.

Originality/value: The article can be used by the Faculty authorities as a recommendation regarding the implementation of the Strategy and in making key strategic decisions.

Keywords: strategy, development, SWOT analysis, strategic analysis. 


\section{Introduction}

Internal and external strategic assessment allows identification of the conditions for an organization's development, indicating, at the same time, the most important elements that shape its market position as well as identify and predict the changes that may affect its proper development. It necessitates a long-term action plan, i.e. a developed strategy.

Strategic analysis is closely related to the management of an organization, which in the literature on the subject is interpreted in various ways, meaning that there is a number of definitions that incorporate its different aspects.

Ricky W. Griffin believes that management entails a set of projects that encompass planning and decision making, organizing, personnel management, and controlling, focused on an organization's resources (human, financial, material and information), implemented with the plan to achieve intended company goals, in a functional and effective manner (Griffin, 1998, pp. 36-39).

A.K. Kozminski presents a slightly different view, stating that "the essence of management is to control diversity and transform a potential conflict into cooperation" (Koźmiński, Jemielniak, 2008, p. 16). He also explains that cooperation is not only about an organization's interior, but it must also include the relations with external entities and should aim to ensure company's survival and development. He also states that management is a kind of a "journey through chaos", a construction of reality with the use of the available material and intangible resources.

Contrastingly, P. Samuelson and D.W. Nordhaus describe the term "enterprise" as denoting a unit that modifies three types of production elements into a good that is equal, long-lasting and fulfills the client's needs. Enterprises are "specialized small, medium and large institutions that manage production processes and dominate the landscape of modern economy" (Samuelson, 1995).

According to Z. Pierścionek, in researching organizations' development, it is important to create a strategy, as well as to apply it and check it, which requires various assessments expressed as strategic analyzes. Strategies entail 'identification of individual stakeholders' goals and expectations, assessment of company environment and development of forecasts for its changes, assessment of company's resources and skills, in the context of the goals and the stakeholders as well as the existing and the forecasted environmental conditions" (Pierścionek, 2003 , p. 88). The author describes strategic analysis, pointing to its very wide scope and characterizing it by different mechanism-, system- and phenomena-related factors under analysis. 
Strategic analysis is focused on two main areas: external analysis, the so-called business environment analysis, and internal analysis, also called the analysis of the company's resources and competences. K. Andrews lists such factors of an organization's environment as: "the sales market, the suppliers market, the capital market, the labor market, competitors, government and local agencies, associations, foundations, universities. These components of business environment should be considered in technological, economic, social and political aspects" (Andrew, 1971, pp. 70-71).

\section{Research methodology}

In research, regardless of the qualitative or the quantitative approach, the research problem plays the primary role. The main research problem raised concerns analysis of the development strategy prepared for the Faculty (a group of university departments concerned with a major division of knowledge), based on the main source document, i.e. the Faculty's Development Strategy for 2012-2020 .

It should be noted that it is important to specify the study aim and the research problem, and, consequently, to assume a research hypothesis.

The research problem formulated earlier constitutes the basis for determination of the working hypotheses:

a) effective management of the Faculty's operation affects achievement of the goal set, i.e. the Faculty's development,

b) efficient monitoring of the Faculty's strategy allows effective operation of the parent organization,

c) a properly prepared strategy should be based on correct recognition of the potential an organization and its environment can offer.

The most important condition for proper resolution of the above-mentioned research problem and verification of the working hypotheses entails adequate selection of research methods, techniques and tools.

\footnotetext{
${ }^{1}$ Original source document title in PL: Strategia Rozwoju Wydziału na lata 2012-2020.
} 


\section{Research results}

Adoption of the strategy assumptions and designation of the implementation areas enable specification of clear strategic goals that determine the orientation of the Faculty's development. The Faculty's Development Strategy for the years 2012-2020 indicates five basic strategic goals.

The first goal is to internationalize the Faculty's activities. The main intermediate goals that accompany the first goal entail: increasing the quality of the teaching processes, up to the level of international standards, and adaptation of the scientific research to the international standards. It can be stated that, as a result of the actions taken at the University, i.e. creation of the System of Education Quality Assurance, included in the Quality Book, an increase in the quality of the activities undertaken is observed every year, which has been expressed by the very good assessment for the Faculty, expressed in the assessment report of the Polish Accreditation Committee. The Faculty Team for the Quality of Training has been operating at the Faculty, which ensures quality in many areas, such as science, didactics, and education.

The second strategic goal concerns the scientific activity carried out by the Faculty, which is mainly related to a system designed to monitor the scientific activity of the teaching staff and their scientific development. As early as in the first years of the current strategy implementation, many scientific and didactic employees attained a doctorate degree or a habilitation (post-doctoral degree), which increased the number of scored publications in journals ranked on the list of the Minister of Science and Higher Education, thus allowing the Faculty to maintain, since 2013, its II category of economic faculties. Conversely, scientific activity of young researchers at the Faculty is directed through the co-financing of selected actions, via targeted subsidies from the Ministry of Science and Higher Education for young researchers' development (BSM).

Another strategic goal entails the educational activity carried out at the Faculty. An important specific goal, within the scope of the main goal, is to provide high quality education, development of the didactic offer through trainings, organization of conferences or support of the students' activity.

Cooperation with the environment is another strategic goal. The basis for achievement of this goal entails, above all, intensive cooperation with the government and the local administration of the cities or municipalities, integration with scientific and social institutions, the effect of which is to create a positive image of the Faculty and to strengthen its position in the region and the country (Strategia Rozwoju..., pp. 19-20). As part of the cooperation with the environment, the Faculty organized regular meetings with employers, to develop the learning outcomes for the academic study majors. 
The last strategic goal of the Faculty is to increase its functional and organizational efficiency. Implementation of management methods that are based on a system of informationgeneration management and on a system of risk analysis, as well as risk diagnosis and monitoring of those systems constitute an important element of the strategic goal (Strategia Rozwoju..., pp. 23-24).

As part of the Faculty's operation, a team for risk management has been appointed, analyzing risk annually, indicating its impact and the level of probability as well as the ways to minimize it.

In addition to the strategic and intermediate goals, the Faculty's Development Strategy presents, in detail, the activities specifying the objectives, which should be included in the process aimed at achievement of the objectives and when formulating the tasks set for individual employees of the Faculty, as well as the measures for assessment of objective achievement and implementation.

The SWOT analysis carried out as part of the process entailing creation of the Faculty's Development Strategy is a traditional tool used for studying an organization's environment and identification of its strengths and weaknesses. The tool was used to diagnose important factors conditioning the development of the Faculty.

First, internal factors had been identified, which then were divided into strengths and weaknesses. In the next stage, external factors were diagnosed and divided into the opportunities and the threats to the unit's development.

In accordance with the criteria adopted and the division obtained, the following description of individual groups of factors has been agreed on:

- strengths - factors that originate in the interior of the Faculty and positively affect its development,

- weaknesses - factors originating in the interior of the Faculty and adversely affect its development,

- opportunities - factors originating in the Faculty's external environment and have positive impact on its development,

- threats - factors originating in the external environment of the Faculty and adversely affect its development.

Table 1 summarizes the Faculty's strengths and weaknesses as well as opportunities and threats.

The Faculty prepares Self-assessment Reports annually. The information these reports contain concerns, among others, SWOT analyzes for individual study majors, i.e. Management, Management and Production Engineering. By listing these factors and presenting them in a report, the Faculty authorities are able to determine the strategic position and how to improve the functioning and the existence of the study majors offered at the Faculty. This analysis reflects the problems the Faculty faces. 
Table 1.

SWOT analysis of the Faculty

\begin{tabular}{|c|c|}
\hline Strengths & Weaknesses \\
\hline $\begin{array}{l}\text { - New premises, enabling optimal organization and } \\
\text { planning of didactic classes; } \\
\text { - Diversified didactic offer, ensuring acquisition of } \\
\text { skills in the use of, among others, IT tools in } \\
\text { organization management; } \\
\text { - Access to the latest IT technologies used in } \\
\text { enterprise management, logistics, human resource } \\
\text { management; } \\
\text { - Education in English, } \\
\text { - Qualified staff with scientific achievements, } \\
\text { didactic and practical experience; } \\
\text { - Continuous scientific development of employees; } \\
\text { - Employee involvement in the development and } \\
\text { operation of the Faculty; } \\
\text { - A student internship program that is compliant with } \\
\text { the requirements of the labor market, ensuring } \\
\text { confrontation of management theory and practice; } \\
\text { - The Faculty's 'young age', resulting in the } \\
\text { dynamics of improving the quality of teaching, } \\
\text { in order to achieve the highest possible reputation on } \\
\text { the higher education market; } \\
\text { - An innovative system of research laboratories, } \\
\text { created as part of the RCI II Project; } \\
\text { - An increase in the number of students of the } \\
\text { academic majors offered; } \\
\text { - Conduction of scientific research in the field of } \\
\text { management sciences, production engineering, and } \\
\text { economics, implemented, among others, under the } \\
\text { grants obtained and the research projects entrusted; } \\
\text { - Operation of the Faculty within a University } \\
\text { structure of a technical and natural profile that is } \\
\text { unique in the region, which creates additional } \\
\text { economic and public administration staff. } \\
\text { opportunities for development, in terms of } \\
\text { management, management and production } \\
\text { engineering, with specific specializations of } \\
\text { a practical and market-oriented slope, e.g. related to } \\
\text { the use of IT in business, bioproduction, logistics, etc. } \\
\text { within the framework of management as well as, } \\
\text { specific specializations with a practical and market- } \\
\text { oriented slope, e.g. related to the use of information } \\
\text { technology in business, bioproduction, logistics, etc. } \\
\text { - equipped library with a collection of } \\
\text { mand books in the field of social sciences, } \\
\text { - economics and legal sciences; }\end{array}$ & $\begin{array}{l}\text { - A too short period of operating on the higher } \\
\text { education market, which hinders development of the } \\
\text { Faculty's brand and prestige; } \\
\text { - Low number of part-time students; } \\
\text { - Low renumeration rates for the scientific and } \\
\text { administrative staff; } \\
\text { - Lack of land development around the Faculty's } \\
\text { premises; } \\
\text { - Low level of international cooperation; } \\
\text { - Low activity in terms of funds acquisition from } \\
\text { external sources. }\end{array}$ \\
\hline
\end{tabular}


Cont. table 1.

\begin{tabular}{|l|l|}
\hline \multicolumn{1}{|c|}{ Opportunities } & \multicolumn{1}{c|}{ Threats } \\
\hline - The Faculty's participation in scientific and research & - Failure to comply with the contract under the \\
grants and in EU projects; & RCI II Project, with regard to research projects. \\
- Increased opportunities for acquisition of external & - Lowering the level of the financial (ministerial) \\
financial funds, including EU funds for & $\begin{array}{l}\text { funds awarded for statutory activities, resulting from } \\
\text { the use of an unfavorable division algorithm for }\end{array}$ \\
implementation of interdisciplinary research projects & newly-created units, which may affect the relatively \\
by young scientists; & low wages and generate a threat of partial loss of \\
- Advanced research processes (postdoctoral & staff, especially the independent employees, who \\
dissertations) will fundamentally affected an increase & might leave for other universities; \\
the number of independent academics; & - The demographic decline; \\
- The Faculty's cooperation with the University's & - The rapidly changing market needs in terms of \\
units and with other research and scientific & higher education; \\
institutions in the country and abroad, with regard to & - The too long wait for changes in the procedures \\
research projects and new didactic offers; & associated with new training offers; \\
- The Faculty's cooperation with foreign universities, \\
creating opportunities for an increase in staff and \\
student mobility; & - Negative consequences of the changes in the rules \\
- Prospects for cooperation with business & for financing a second, parallel study major; \\
organizations and public administration; & - The economic crisis in the country, which translates \\
- An increasing number of graduates majoring in & into bad financial situation of potential students \\
technical and natural science specializations, who are & applying to the Faculty \\
interested in further education in management & \\
\hline
\end{tabular}

Source: Faculty's Development Strategy for the years 2012-2020 [original title in Polish: Strategia Rozwoju Wydziału na lata 2012-2020].

\section{Conclusion}

Considering the development of the environment, a deepening scientific attitude towards the methods that improve the forecasting of changes in the environment and the increasingly effective adaptation to this environment can be noticed. Recently, emphasis has been placed on analysis as a multi-faceted approach to strategy, with a focus on 'strategic thinking'. 'To think strategically' means:

- to strive to understand the circumstances, analyze opportunities, choose the intentions of and the rules for resource use, moving forward with the idea,

- to use procedures as well as assessment and synthesis techniques to accomplish these aspirations and collect the necessary information,

- to be characterized by readiness to constantly change the scope and the types of organization functioning, in accordance with the change in a company's vision and the state of its environment (Gierszewska, Romanowska, 2003, p. 18).

Diagnosis of an organization and its environment is necessary when preparing a development strategy that is appropriate for the organization. That is why it is so important to know its strengths, weaknesses, opportunities and threats. 
Based on the analysis of the Faculty's interior and surroundings, it needs to be stated that the Faculty's Development Strategy should be evaluated in the near future. A strategymonitoring system should also be developed, taking into account the results obtained. Expansion of international cooperation, in the field of research, is becoming necessary. An increase in active participation of the Faculty's scientific staff in international conferences and publishing should also take place.

In terms of further development, it is necessary to develop a Staff Development Strategy, which may accelerate the Faculty's independence and, consequently, the rights to attainment of a doctorate degree.

\section{References}

1. Andrew, K. (1971). The Concept of Corporate Strategy. Homewood: Dow Jones-Irvin.

2. Gierszewska, G., Romanowska, M. (2003). Analiza strategiczna przedsiębiorstwa. Warszawa: PWE.

3. Griffin, R.W. (1998). Podstawy zarzadzania organizacjami. Warszawa: PWN.

4. Koźmiński, A.K., Jemielniak, D. (2008). Zarządzanie od podstaw. Warszawa: WAiP.

5. Pierścionek, Z. (2003). Strategie konkurencji i rozwoju przedsiębiorstwa. PWN.

6. Samuelson, P., Nordhaus, W.D. (1995). Ekonomia. Warszawa: PWN.

7. Strategia Rozwoju Wydziału na lata 2012-2020. 